\title{
COUNSELING OF FAMILY FINANCIAL MANAGEMENT LITERACY PROGRAM KELUARGA HARAPAN BENEFICIARIES
}

\author{
Sabinus BENI'1, Blasius MANGGU2', Yosua Damas SADEWO³ \\ Program Studi Kewirausahaan, Sekolah Tinggi Ilmu Manajemen Shanti Bhuana \\ Email: sabinusbeni@gmail.com
}

\begin{abstract}
Community service was carried out in Setia Budi Village, Bengkayang District, West Kalimantan. The event was held on February 18, 2019 with 97 participants as Pre-Prosperous Family beneficiaries of the Hope Family Program. The purpose of this activity is that the families of the beneficiaries of the family program hope to manage their wealth well so that the assistance in the form of cash received is right on target and managed well. The method used in the form of lectures and question and answer and the practice of directly preparing the family financial budget. The results expected in this activity are to assist the government in managing family finances so that beneficiary families can graduate independently from their participation as beneficiaries of family program expectations because economy has increased.
\end{abstract}

Key Words: literacy, pre-prosperity, credit union, empowerment.

\section{PENDAHULUAN}

Desa Setia Budi merupakan salah satu Desa yang berada di Kecamatan Bengkayang, berbatasan langsung dengan Kecamatan Suti Semarang, Lumar, Teriak, dan Ledo. Mayoritas masyarakat bekerja sebagai petani. Jarak tempuh dari Kampus Sekolah Tinggi IImu Manajemen (STIM) Shanti Bhuana menuju lokasi sekitar 45 Menit melalui jalan darat.

Mitra kegiatan Pengabdian adalah Keluarga Penerima Manfaat Program Keluarga Harapan di Desa Setia Budi Kecamatan Bengkayang dengan Jumlah Penduduk Pra Sejahtera yang menerima bantuan Sosial Program Keluarga Harapan (PKH) sebanyak 97 Orang Kepala Keluarga. Permasalahan utama yang terjadi yaitu terkait pengelolaan keuangan yang berkaitan dengan bantuan PKH. Harapan setelah kegiatan penyuluhan ini, masyarakat penerima manfaat PKH dapat mengelola keuangan dengan baik dapat dapat keluar/graduasi dari PKH karena taraf hidup telah meningkat ataupun sudah mandiri.

Permasalah utama diadakannya kegiatan ini adalah terkait kendala keluarga pra sejahtera dalam pengelolaan keuangan keluarga. Hal ini membuat kondisi ekonomi keluarga penerima manfaat PKH tidak mengalami peningkatan taraf hidup. Permasalahan ini jika dibiarkan akan berdampak negatif bagi tujuan Program Keluarga Harapan. Maka, kami mencoba membantu memberikan penyuluhan terkait literasi pengelolaan keuangan yang sederhana bagi Keluarga Penerima Manfaat PKH di Desa Setia Budi. 


\section{KAJIAN TEORI}

\section{Program Keluarga Harapan}

Program Keluarga Harapan (PKH) merupakan program pengentasan kemiskinan dari Kementerian Sosial Republik Indonesia sejak tahun 2007. Dalam perkembangannya, PKH pada masa pemerintahan Presiden Joko Widodo mengalami banyak perubahan terkait mekanisme dan persyaratan kepesertaan, antara lain Sasaran PKH merupakan keluarga miskin dan rentan yang terdaftar dalam Data Terpadu Program Penanganan Fakir Miskin yang memiliki komponen kesehatan dengan kriteria ibu hamil/menyusui, anak berusia nol samapai dengan enam tahun. Komponen pendidikan dengan kriteria anak SD/MI atau sederajat, anak SMA/MTs atau sederjat, anak SMA /MA atau sederajat, dan anak usia enam sampai 21 tahun yang belum menyelesaikan wajib belajar 12 tahun.

\section{Pengelolaan Keluangan Keluarga}

Pengaturan Keuangan Keluarga, mengapa harus dilakukan?

- Pendapatan terbatas

- Pengeluaran tidak terbatas

- Harga barang cenderung naik

- Setiap keluarga mempunyai tujuan keuang-an yang ingin di capai

- Jaminan kesejahteraan masa depan

Prinsip-prinsip pengaturan pengeluaran

- Mengatur agar pengeluaran selalu lebih kecil dari pendapatan

- Memanfaatkan pendapatan untuk membayar pengeluaran-pengeluaran setiap bulan

- Menetapkan prioritas kebutuhan

Pola pengaturan keuangan adalah:

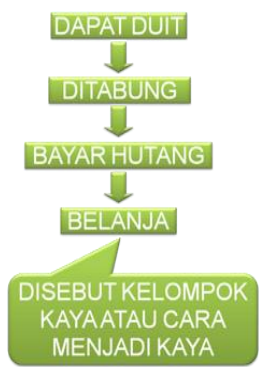

Gambar: cara mengelola keuangan

Ligwina (2019) memberikan beberapa kunci untuk mengelola keuangan secara sederhana:

\section{Pahami portfolio keuangan keluarga Anda.}

Jangan sampai Anda tak tahu isi tabungan, jumlah tagihan listrik, telepon, servis mobil, belanja, biaya periksa dokter dan lainnya. Anda harus tahu berapa hutang kartu kredit, pinjaman bank atau cicilan rumah dan mobil.

\section{Susun rencana keuangan atau anggaran.}

Rencana keuangan yang realistis membantu Anda bersikap obyektif soal pengeluaran yang berlebihan. Tak perlu terlalu ideal, sehingga lupa kebutuhan diri sendiri. Tak ada salahnya memasukkan kebutuhan pergi ke salon, spa atau clubbing. Yang penting, anggarkan jumlah yang realistis dan Anda pun harus patuh dengan anggaran tersebut. 


\section{Pikirkan lebih seksama pengertian antara "butuh" dan "ingin".}

Tak jarang kita membelanjakan uang untuk hal yang tak terlalu penting atau hanya didorong keinginan, bukan kebutuhan. Buatlah daftar berupa tabel yang terdiri dari kolom untuk item belanja, kebutuhan dan keinginan. Setelah mengisi kolom item belanja, isilah kolom "kebutuhan" dan "keinginan" dengan tanda cek (V). Dari sini pertimbangkan dengan lebih matang, benda atau hal yang perlu Anda beli/penuhi atau tidak.

4. Hindari hutang.

Godaan untuk hidup konsumtif semakin besar. Tapi bukan berarti dengan mudah Anda membeli berbagai benda secara kredit. Tumbuhkan kebiasaan keuangan yang sehat dimulai dari yang sederhana, seperti tak memiliki hutang konsumtif.

\section{Meminimalkan belanja konsumtif.}

Bertemu teman lama untuk bertukar pikiran di kafe terkadang memang perlu, tapi tak berarti Anda harus melakukannya di setiap Jumat sore. Anda bisa gunakan pengeluaran ini untuk menabung atau memenuhi kebutuhan lain.

\section{Tetapkan tujuan atau cita-cita finansial.}

Susun target keuangan yang ingin Anda raih secara berkala, bersama pasangan. Tetapkan tujuan spesifik, realistis, terukur dan dalam kurun waktu tertentu. Tujuan ini membantu Anda lebih fokus merancang keuangan. Misalnya, bercita-cita punya dana pendidikan prasekolah berstandar internasional dan sebagainya.

\section{Menabung, menabung, menabung.}

Ubah kebiasaan dan pola pikir. Segera setelah menerima gaji, sisihkan untuk tabungan dalam jumlah yang telah Anda rencanakan sesuai tujuan atau cita-cita finansial keluarga Anda. Sebaiknya, Anda memiliki rekening terpisah untuk tabungan dan kebutuhan sehari-hari.

\section{Berinvestasilah!}

Tentu Anda tak akan puas dengan hanya menunggu tabungan membumbung. Padahal cita-cita Anda untuk keluarga "selangit". Inilah saat yang tepat untuk juga memikirkan investasi. Kini bentuknya macam-macam. Takut akan risiko investasi?! Tak perlu khawatir, Anda hanya perlu belajar pada ahlinya. Konsultasikan keuangan Anda dengan ahli keuangan yang handal!

\section{METODE PELAKSANAAN}

Metode pelaksanaan kegiatan ini adalah:

1) Koordinasi dengan Kepala Desa Setia Budi tentang rencana Penyuluhan

2) Koordinasi dengan Pendamping Sosial PKH Kecamatan Bengkayang

3) Pembuatan Undangan Penyuluhan

4) Menyiapkan Materi Penyuluhan

5) Pembuatan ljin/surat tugas Pengabdian Pada Masyarakat (PPM) dari Kampus STIM Shanti Bhuana 
6) Pelaksanaan Penyuluhan bagi 97 KPM Program Keluarga Harapan di Kantor Desa Setia Budi

- Ceramah

- Tanya jawab

- Praktik pembuatan anggaran keuangan keluarga
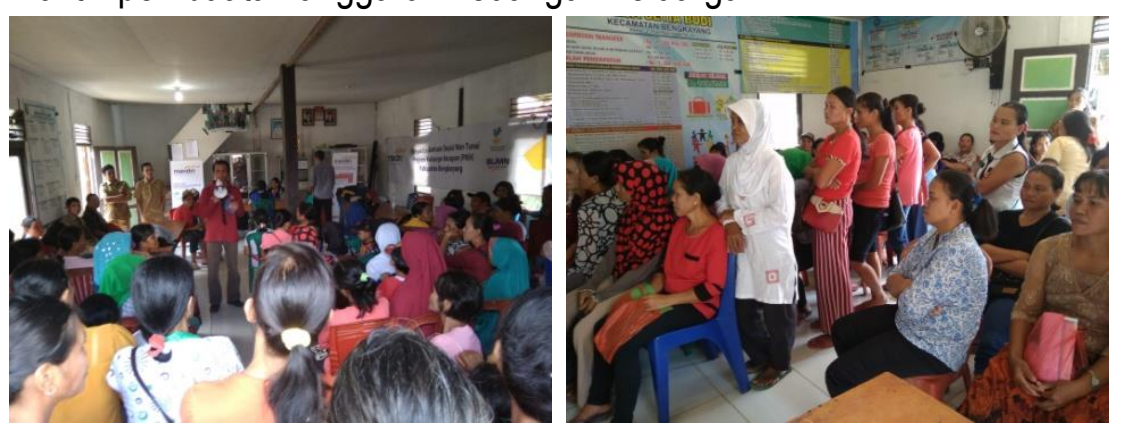

Gambar: Tanya jawab pengelolaan keuangan Gambar: Peserta (Ibu KPM PKH Desa Setia Budi)

7) Pembuatan Laporan

8) Evaluasi pelaksanaan/penerapan pengelolaan keuangan KPM PKH dengan kunjungan langsung dan wawancara terkait pengelolaan keuangan

\section{HASIL DAN PEMBAHASAN}

Kegiatan ini diawali terlebih dahulu dengan melakukan koordinasi dengan kepala desa Setia Budi dan Pendamping Sosial PKH Kecamatan Bengkayang terkait permasalahan yang dialami oleh KPM PKH Kecamatan Bengkayang. Dari hasil koordinasi tersebut disimpulkan bahwa materi yang cocok untuk disampaikan adalah tentang ppengelolaan keuangan keluarga yang dilanjutkan dengan menyiapkan materi penyuluhan bersama tim dosen STIM Shanti Bhuana serta pembuatan undangan dan surat tugas penyuluhan sebagai kegiatan pengabdian masyarakat dari Pusat Riset dan Pengabdian Masyarakat STIM Shanti Bhuana.

Kegiatan dilaksanakan di Kantor Desa Setia Budi tanggal 18 Februari 2019 mulai Pukul 08.05 WIB sampai pukul 12.30 WIB dengan 97 orang peserta berasal dari KPM PKH Desa Setia Budi, adapun uturan kegiatan sebagai berikut:

1) Pengantar dari Pendamping Sosial PKH Kecamatan Bengkayang

2) Sambutan dari Kepala Desa Setia Budi sekaligus membuka kegiatan penyuluhan

3) Penyampaian materi (Ceramah dengan bantuan media berupa Proyektor) meliputi; Pengantar Pengaturan Keuangan Keluarga, Sumber Pendapatan, Cara Mengelola Keuangan, Sikap Dasar Mengatur Keluangan Keluarga Yang Baik, Cara Mudah dan Sederhana Menyusun Anggaran Keuangan Keluarga (ABK).

4) Tanya Jawab

5) Praktik membuat $A B K$

6) Penutup, dilanjutkan

7) Pembuatan laporan kegiatan 
8) Evaluasi Kegiatan (kunjungan langsung bulan ke-3 (mei) terkait rekomendasi pengelolaan keuangan keluarga: menabung di Credit Union.

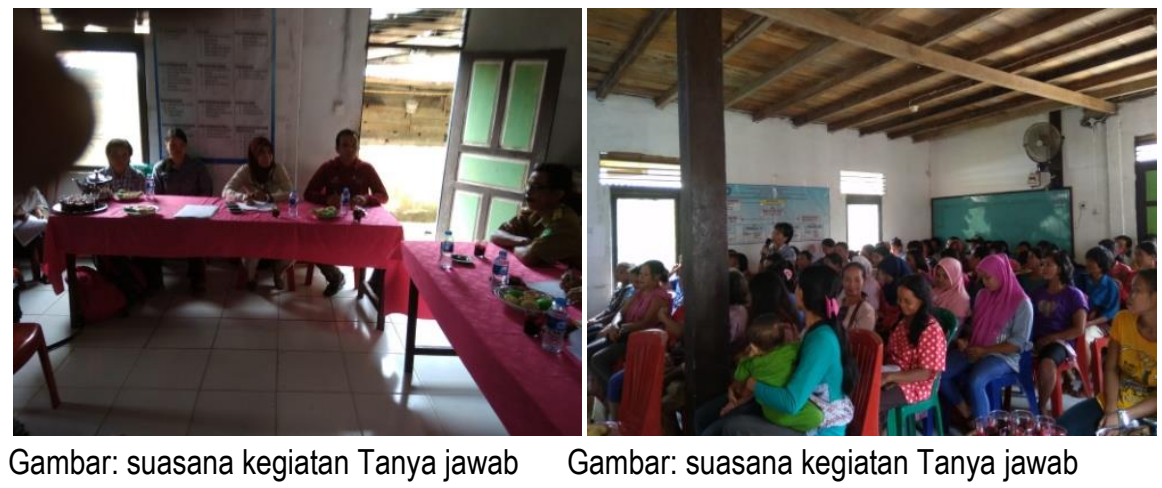

Sebanyak 97 orang peserta PPM terlihat sangat antusias dalam mengikuti kegiatan dan melakukan praktik langsung pembuatan ABK. Untuk memastikan kegiatan ini bermanfaat dengan baik, Tim Pengabdian Pada Masyarakat bekerjasama dengan Pendamping Sosial PKH Kecamatan Bengkayang untuk memonitoring progress menabung KPM di Credit Union maupun Bank yang mereka pilih.

\section{SIMPULAN}

Mitra kegiatan sangat antusias dalam kegiatan ini mulai dari Pihak Desa Setia Budi, Pendamping Sosial PKH Kecamatan Bengkayang dan Seluruh Keluarga Penerima Manfaat Program Keluarga Harapan di Desa Setia Budi dalam mengikuti Penyuluhan dan Praktik Pengelolaan Keuangan Keluarga. Hal tersebut terpantau dari kegiatan monitoring yang dilakukan oleh Tim PPM dari STIM Shanti Bhuana pada bulan ketiga (bulan Mei) dimana dari 97 orang KPM sebanyak 69 orang telah memiliki rekening tabungan di Credit Union dan 10 orang memiliki rekening Bank atau sebanyak 79 orang telah memiliki rekening tabungan. 


\section{REFERENSI}

Kementerian Sosial Republik Indonesia, 2019. Program Keluarga Harapan, https://www.kemsos.go.id/program-keluarga-harapan, diakses tanggal 25 Juni 2019.

Ligwina, 2019. Cara Sederhana Mengelola Keuangan Keluarga, https://www.ayahbunda.co.id/keluargakeuangan/cara-sederhana-mengelola-keuangan-keluarga, diakses tanggal 25 Juni 2019.

Munaldus dkk, 2013. Hidup Berkelimpahan Bersama Credit Union, Jakarta, Gremedia.

Sabinus Beni, 2018. Program Keluarga Harapan Dalam Menumbuhkan Jiwa Wirausaha. JURKAMI Volume 3 No. 2 Tahun 2018.

Sabinus Beni, 2017. Pembangunan Manusia Melalui Pendidikan Dasar Credit Union. Jakarta. Mer-C Publishing.

Yosua Damas Sadewo, 2017. Hambatan dan Tantangan Program Studi Kewirausahaan di Wilayah Perbatasan. Mabis Volume 8 No.1 Tahun 2017. 